\title{
River fragmentation and fish population structure: a comparison of three Swiss midland rivers
}

\author{
Alexandre Gouskov ${ }^{1,2,3}$ and Christoph Vorburger ${ }^{1,2,4}$ \\ ${ }^{1}$ Institute of Integrative Biology, ETH Zürich, Universitätstrasse 16, 8092 Zürich, Switzerland \\ ${ }^{2}$ Aquatic Ecology, Eawag, Überlandstrasse 133, P.O. Box 611, 8600 Dübendorf, Switzerland
}

\begin{abstract}
Anthropogenic river fragmentation has the potential to alter fish population structure and diversity, but it can be difficult to infer whether observed effects reflect the obstruction of fish movement or population responses to altered flow regimes or habitat structure concomitant with fragmentation. We addressed the influence of habitat fragmentation on the European Chub (Squalius cephalus), a large-bodied fish with strong swimming ability that is a ubiquitous habitat generalist that occurs at high densities in lentic and lotic habitats. European Chub populations have never been stocked and are little affected by habitat alterations. Thus, they are good sentinels for the effects of fragmentation per se. We used microsatellite genotyping of 1726 fish from 38 sites to compare the genetic structure and diversity of European Chub populations from 3 Swiss midland rivers that are unequally affected by man-made fragmentation. The Thur is unfragmented, the adjacent Glatt is strongly fragmented by tall barriers, and the Broye is fragmented by a large number of low barriers that are individually traversable. European Chub from the Thur possessed the highest allelic diversity overall and showed no significant isolation-by-distance and only a weak nonsignificant upstream decline in genetic diversity. European Chub from the Glatt were less genetically diverse and showed significant isolation-by-distance that was explicable by existing barriers and the presence of a lake in the system and a steep upstream decline of allelic diversity. European Chub from the Broye showed no genetic substructure, suggesting that barriers of low height, even when numerous, had little effect on population connectivity. The detectable effects of anthropogenic fragmentation of rivers on a highly mobile fish like the European Chub suggests that less mobile species, such as habitat specialists or small benthic species, are potentially more vulnerable to isolation.
\end{abstract}

Key words: habitat fragmentation, population connectivity, isolation-by-distance, conservation genetics, Squalius cephalus

Pressure on river landscapes is enormous in areas with high human population density. Demand for agricultural land or building grounds and their protection from flooding have necessitated river corrections with a concomitant loss of floodplains, and regulated rivers are frequently interrupted by hydroelectric power stations, dams, and weirs. Switzerland is a case in point: $95 \%$ of floodplains have been lost (Tockner and Stanford 2002), and Swiss streams and rivers are fragmented by $>100,000$ artificial barriers (Zeh Weissmann et al. 2009).

Habitat fragmentation is considered a key threat to fish populations worldwide (Vörösmarty et al. 2010). The most obvious reason is that barriers interrupt migratory life cycles, and most globally and locally threatened species have diadromous life histories (Penczak et al. 1998, Kirchhofer et al. 2007, Limburg and Waldman 2009, Liermann et al. 2012). In Switzerland, for example, the Atlantic salmon has been considered extinct since the 1950s because its migration route along the Rhine is obstructed by numerous barriers (Gerster 1991). Barriers also affect the distribution of nonmigratory fish species in rivers (McLaughlin et al. 2006), and they may diminish river restoration potential by hampering recolonization (Stoll et al. 2013). Even without migration to or from the sea, some fish species require up to $100 \mathrm{~km}$ of river to complete their entire life history (Fausch et al. 2002).

The genetic effects of habitat fragmentation on riverine fish are another important concern. Reduced gene flow among populations is expected to result in reduced withinpopulation genetic diversity, which may eventually affect the ability of populations to respond to environmental change (Stockwell et al. 2003). Construction of migration barriers tends to be accompanied by changes in flow regime and habitat characteristics. Thus, inferring whether reduced pop-

E-mail addresses: ${ }^{3}$ alexandre.gouskov@eawag.ch; ${ }^{4}$ To whom correspondence should be addressed, christoph.vorburger@eawag.ch

DOI: 10.1086/685658. Received 9 July 2015; Accepted 28 September 2015; Published online 9 February 2016.

Freshwater Science. 2016. 35(2):689-700. ๑ 2016 by The Society for Freshwater Science. 
ulation connectivity and loss of genetic variation are a consequence of physical obstruction to dispersal or of the creation of inhospitable habitat can be difficult. For example, construction of reservoirs may isolate fish populations among streams that feed into the reservoirs even without physical barriers because the lentic habitat represents a barrier to dispersal by fishes adapted to lotic conditions (Hudman and Gido 2013, Fluker et al. 2014). Impoundments also may degrade or reduce access to specific habitats required by specialists. Man-made structures affect population differentiation and genetic diversity of the endangered Macquarie Perch (Macquaria australasica) in southeastern Australia (Faulks et al. 2011), but whether the structures acted by obstructing dispersal or by reducing availability and access to riffle habitat required by this species was not clear. Isolation by habitat alteration is a lesser issue for habitat generalists, like the European Chub (Squalius cephalus), which therefore, is a suitable sentinel for the effects of physical obstruction to dispersal per se. The European Chub has coped well with the massive alteration of river habitats taking place in the densely populated areas of Switzerland and is highly abundant in virtually all lotic and lentic waters of the Swiss midland. However, like any other fish, it is likely to be affected by physical barriers to migration. The European Chub is of no commercial interest. Its population and genetic structure are likely to be affected by habitat fragmentation, but any effects are unconfounded by stocking. We used this situation as an opportunity to investigate how man-made obstacles to migration affect the genetic population structure and diversity of fish populations. We sampled European Chub along 3 rivers in the Swiss midlands that differ in their level of anthropogenic fragmentation, and we genotyped them based on microsatellites to compare population connectivity and genetic diversity among the 3 rivers.

\section{METHODS}

\section{Study species}

The European Chub is distributed across Europe from the Pyrenees to the Urals, excluding the Iberian, Italian, and Greek peninsulas. Its northern distribution extends to $\sim 56^{\circ} \mathrm{N}$ (Kottelat and Freyhof 2007). It occurs at relatively low altitudes (typically $<800 \mathrm{~m}$ asl), where it is a habitat generalist that occupies lotic and lentic habitats (Zaugg et al. 2003). European Chub grow to an average maximum length of $50 \mathrm{~cm}$ and reach maturity after 2 to $3 \mathrm{y}$. Spawning takes place in spring on gravel substrate. As fractional spawners, European Chub spawn more than once during a season (Kottelat and Freyhof 2007). In a radio-tagging study at the River Spree in Germany, females spawned twice after spawning migrations of up to $16 \mathrm{~km}$, and some females changed spawning grounds between the $1^{\text {st }}$ and $2^{\text {nd }}$ spawning event (Fredrich et al. 2003). In the French River Meuse, rapid spawning migrations of up to $25 \mathrm{~km}$ were observed, suggesting that European Chub are powerful swimmers (de Leeuw and Winter 2008).

\section{Study rivers}

We investigated European Chub populations in 3 rivers of the Swiss midlands. The Broye is in the western part of Switzerland, and the Glatt and Thur are in the eastern part (Fig. 1A, B). All 3 rivers are channelized over much of their length, but they differ in the degree of anthropogenic fragmentation. The Glatt and Thur are adjacent tributaries to the Rhine. Their confluences with the Rhine are $14 \mathrm{~km}$ apart (riparian distance). Our choice of these 2 rivers enabled us to make the most direct comparison to assess fragmentation effects because the Thur is unfragmented by any migration barriers along the $\sim 80 \mathrm{~km}$ we investigated, whereas the Glatt is heavily fragmented by a total of 35 barriers (Fig. 1C). European Chub cannot transverse most of these barriers in the upstream direction except for twelve 50 - to $100-\mathrm{cm}$ barriers that may be traversable when water levels are high. The Broye differs from both the Thur and the Glatt in that it is heavily fragmented by 35 weirs of low height $(40-50 \mathrm{~cm})$ and one small natural drop. European Chub can pass each of these barriers, but the barriers may exert a cumulative effect on population connectivity (Fig. 1B). The Thur is the largest of the 3 rivers (average discharge $\left.=47 \mathrm{~m}^{3} / \mathrm{s}\right)$, followed by the Broye $\left(11.50 \mathrm{~m}^{3} / \mathrm{s}\right)$ and the Glatt $\left(8.42 \mathrm{~m}^{3} / \mathrm{s}\right)$. For comparison, the Rhine has an average discharge of $441 \mathrm{~m}^{3} / \mathrm{s}$ where it is entered by the Thur and the Glatt.

The upper part of the heavily fragmented Glatt drainage is somewhat complex in structure (Fig. 1C). It includes Lake Greifen $\left(8.45 \mathrm{~km}^{2}\right)$, which feeds the Glatt and 2 main tributaries named Aabach-U $\left(1.60 \mathrm{~m}^{3} / \mathrm{s}\right)$ and Aabach-M $\left(1.04 \mathrm{~m}^{3} / \mathrm{s}\right)(\mathrm{U}$ and $\mathrm{M}$ stand for the towns Uster and Mönchaltorf, which the 2 streams traverse). The smaller Lake Pfäffikon $\left(3.3 \mathrm{~km}^{2}\right)$ east of Lake Greifen drains into Aabach$\mathrm{U}$ and, thus, also is connected to the Glatt. Anthropogenic fragmentation of the Glatt system began in 1822 with the construction of the most downstream barrier (Fig. 1C), and increased gradually with the construction of mills and several flood-protection projects, including numerous weirs, during the $19^{\text {th }}$ and $20^{\text {th }}$ centuries (Vischer 2003). The only natural barrier (age unknown) is the uppermost, just below Lake Pfäffikon (Fig. 1C).

\section{Sampling procedure}

We used European Chub from 38 collection sites, including 23 from the Glatt system, 9 from the Thur and Rhine, and 6 from the Broye (Table 1). We caught European Chub from spring to autumn in 2010 and 2011 by electrofishing (FEG 1700; EFKO, Leutkirch, Germany), except for sites G9 and G21 (Fig. 1C), where rod and line were used. We anaesthetized fish lightly with clove oil before cutting $\sim 1 \mathrm{~mm}^{2}$ of the caudal fin as a tissue sample. After recovery, we released all fish at the place of catch. We stored fin clips in 99\% EtOH until use. Sample sizes ranged from 19 to 53 individuals with an average of 45 fish/ site. 

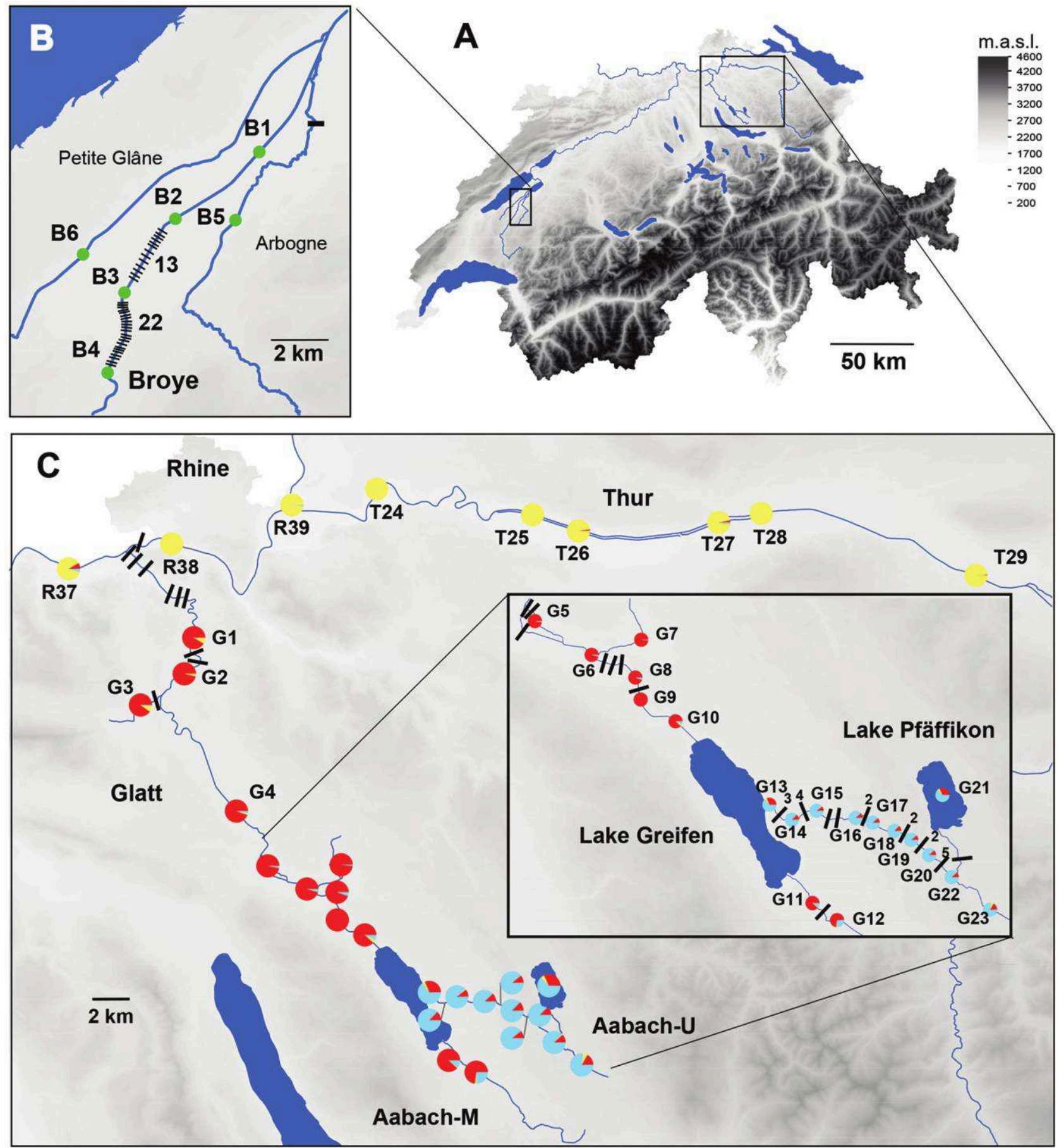

Figure 1. Map of Switzerland indicating the locations of the river systems studied (A) and details of sampling sites in the Broye (B) and the Thur and Glatt systems (C). In panel B, the thin bars represent fragmentation by a series of barriers of low height $(40-50 \mathrm{~cm})$ with the exact number indicated to the right. The only natural barrier is indicated by the wider black bar. In panel C, the thin bars represent single barriers or multiple adjacent barriers when accompanied by a figure indicating their number. The only natural barrier is between sites G21 and G22, a natural drop in terrain that is also obstructed by a hydroelectric power station. Colored sectors in pie charts represent the average assignment probability of European Chub from a given sampling site to each of the 3 genetic clusters inferred with a Bayesian clustering analysis done with the software TESS (see Results). Labeling of sampling locations corresponds to Table 1. 
Table 1. Collection information and measures of genetic diversity for 38 samples of European Chub (Squalius cephalus) from the Broye (B), Glatt (G), and Thur (T) systems, including 3 sites from the Rhine (R) already reported by Gouskov et al. (2016). $N=$ sample size, $H_{e}=$ expected heterozygosity, $H_{o}=$ observed heterozygosity, $A R$ = allelic richness standardized for the smallest sample size (19), $F_{I S}=$ inbreeding coefficient, $N_{e}$ = effective population size. The tests for deviations from Hardy-Weinberg equilibrium (HWE) used the randomization approach implemented in FSTAT (version 2.9.3.2). The $p$-value reported represents the proportion of randomizations producing a smaller $F_{I S}$ value than observed when $F_{I S}<0$ (heterozygote excess) and the proportion of randomizations producing a larger $F_{I S}$ value than observed when $F_{I S}>0$ (heterozygote deficit).

\begin{tabular}{|c|c|c|c|c|c|c|c|c|}
\hline Site & Coordinates WGS84 & $N$ & $H_{e}$ & $H_{o}$ & $A R$ & $F_{I S}$ & HWE test & $N_{e}$ estimate \\
\hline G1 & $47^{\circ} 31^{\prime} 51.25 \mathrm{~N}, 8^{\circ} 31^{\prime} 15.24 \mathrm{E}$ & 50 & 0.683 & 0.707 & 6.648 & -0.036 & 0.103 & $115(69-275)$ \\
\hline G2 & $47^{\circ} 30^{\prime} 45.67 \mathrm{~N}, 8^{\circ} 30^{\prime} 48.33 \mathrm{E}$ & 47 & 0.676 & 0.682 & 6.370 & -0.009 & 0.378 & $\infty(314-\infty)$ \\
\hline G3 & $47^{\circ} 29^{\prime} 58.65 \mathrm{~N}, 8^{\circ} 29^{\prime} 34.61 \mathrm{E}$ & 30 & 0.649 & 0.659 & 5.829 & -0.016 & 0.370 & $41.6(21-171)$ \\
\hline G4 & $47^{\circ} 2635.40 \mathrm{~N}, 8^{\circ} 33^{\prime} 03.70 \mathrm{E}$ & 49 & 0.636 & 0.632 & 5.752 & 0.007 & 0.407 & $147(58-\infty)$ \\
\hline G5 & $47^{\circ} 24^{\prime} 55.33 \mathrm{~N}, 8^{\circ} 34^{\prime} 25.38 \mathrm{E}$ & 50 & 0.624 & 0.612 & 5.435 & 0.019 & 0.250 & $\infty(179-\infty)$ \\
\hline G6 & $47^{\circ} 24^{\prime} 12.00 \mathrm{~N}, 8^{\circ} 36^{\prime} 09.54 \mathrm{E}$ & 50 & 0.623 & 0.622 & 5.523 & 0.001 & 0.505 & $236(88-\infty)$ \\
\hline G7 & $47^{\circ} 24^{\prime} 30.04 \mathrm{~N}, 8^{\circ} 37^{\prime} 41.37 \mathrm{E}$ & 45 & 0.623 & 0.615 & 5.357 & 0.014 & 0.335 & $\infty(184-\infty)$ \\
\hline G8 & $47^{\circ} 23^{\prime} 42.60 \mathrm{~N}, 8^{\circ} 37^{\prime} 28.77 \mathrm{E}$ & 46 & 0.638 & 0.652 & 5.408 & -0.023 & 0.251 & $338(83-\infty)$ \\
\hline G9 & $47^{\circ} 23^{\prime} 15.32 \mathrm{~N}, 8^{\circ} 37^{\prime} 09.42 \mathrm{E}$ & 24 & 0.637 & 0.638 & 5.081 & -0.001 & 0.498 & $359(43-\infty)$ \\
\hline G10 & $47^{\circ} 22^{\prime} 47.66 \mathrm{~N}, 8^{\circ} 38^{\prime} 42.78 \mathrm{E}$ & 49 & 0.652 & 0.652 & 6.083 & 0.000 & 0.478 & $148(65-\infty)$ \\
\hline G11 & $47^{\circ} 18^{\prime} 57.06 \mathrm{~N}, 8^{\circ} 42^{\prime} 49.33 \mathrm{E}$ & 48 & 0.677 & 0.670 & 6.041 & 0.010 & 0.380 & $296(96-\infty)$ \\
\hline G12 & $47^{\circ} 18^{\prime} 35.19 \mathrm{~N}, 8^{\circ} 43^{\prime} 34.09 \mathrm{E}$ & 50 & 0.674 & 0.678 & 6.111 & -0.005 & 0.466 & $599(114-\infty)$ \\
\hline G13 & $47^{\circ} 21^{\prime} 00.76 \mathrm{~N}, 8^{\circ} 41^{\prime} 32.62 \mathrm{E}$ & 48 & 0.665 & 0.655 & 5.766 & 0.015 & 0.319 & $115(53-2375)$ \\
\hline G14 & $47^{\circ} 20^{\prime} 41.81 \mathrm{~N}, 8^{\circ} 42^{\prime} 14.48 \mathrm{E}$ & 50 & 0.632 & 0.650 & 5.137 & -0.030 & 0.170 & $87(36-\infty)$ \\
\hline G15 & $47^{\circ} 20^{\prime} 52.43 \mathrm{~N}, 8^{\circ} 42^{\prime} 59.48 \mathrm{E}$ & 48 & 0.637 & 0.619 & 5.107 & 0.028 & 0.181 & $499(70-\infty)$ \\
\hline G16 & $47^{\circ} 20^{\prime} 42.78 \mathrm{~N}, 8^{\circ} 44^{\prime} 11.29 \mathrm{E}$ & 31 & 0.630 & 0.660 & 5.223 & -0.047 & 0.119 & $543(72-\infty)$ \\
\hline G17 & $47^{\circ} 20^{\prime} 36.51 \mathrm{~N}, 8^{\circ} 44^{\prime} 42.48 \mathrm{E}$ & 48 & 0.633 & 0.615 & 5.108 & 0.030 & 0.160 & $72(36-327)$ \\
\hline G18 & $47^{\circ} 20^{\prime} 25.58 \mathrm{~N}, 8^{\circ} 45^{\prime} 23.14 \mathrm{E}$ & 47 & 0.627 & 0.623 & 5.011 & 0.006 & 0.414 & $44(24-116)$ \\
\hline G19 & $47^{\circ} 20^{\prime} 14.06 \mathrm{~N}, 8^{\circ} 45^{\prime} 53.44 \mathrm{E}$ & 46 & 0.633 & 0.638 & 5.069 & -0.007 & 0.442 & $451(52-\infty)$ \\
\hline G20 & $47^{\circ} 19^{\prime} 54.49 \mathrm{~N}, 8^{\circ} 46^{\prime} 25.35 \mathrm{E}$ & 49 & 0.633 & 0.659 & 5.293 & -0.040 & 0.094 & $137(46-\infty)$ \\
\hline G21 & $47^{\circ} 21^{\prime} 08.78 \mathrm{~N}, 8^{\circ} 46^{\prime} 50.51 \mathrm{E}$ & 19 & 0.667 & 0.678 & 6.000 & -0.018 & 0.391 & $152(27-\infty)$ \\
\hline G22 & $47^{\circ} 19^{\prime} 26.78 \mathrm{~N}, 8^{\circ} 47^{\prime} 06.52 \mathrm{E}$ & 45 & 0.639 & 0.625 & 5.208 & 0.022 & 0.228 & $29(20-44)$ \\
\hline G23 & $47^{\circ} 18^{\prime} 45.03 \mathrm{~N}, 8^{\circ} 48^{\prime} 15.89 \mathrm{E}$ & 50 & 0.592 & 0.585 & 4.536 & 0.013 & 0.317 & $32(17-81)$ \\
\hline $\mathrm{T} 24$ & $47^{\circ} 36^{\prime} 15.24 \mathrm{~N}, 8^{\circ} 39^{\prime} 34.38 \mathrm{E}$ & 44 & 0.719 & 0.686 & 7.559 & 0.046 & 0.041 & $340(112-\infty)$ \\
\hline $\mathrm{T} 25$ & $47^{\circ} 35^{\prime} 24.65 \mathrm{~N}, 8^{\circ} 46^{\prime} 29.27 \mathrm{E}$ & 50 & 0.750 & 0.738 & 7.071 & 0.016 & 0.271 & $\infty(467-\infty)$ \\
\hline T26 & $47^{\circ} 34^{\prime} 53.36 \mathrm{~N}, 8^{\circ} 48^{\prime} 31.72 \mathrm{E}$ & 49 & 0.730 & 0.740 & 7.402 & -0.014 & 0.294 & $\infty(413-\infty)$ \\
\hline $\mathrm{T} 27$ & $47^{\circ} 35^{\prime} 04.79 \mathrm{~N}, 8^{\circ} 54^{\prime} 48.78 \mathrm{E}$ & 49 & 0.728 & 0.719 & 7.062 & 0.013 & 0.322 & $\infty(392-\infty)$ \\
\hline $\mathrm{T} 28$ & $47^{\circ} 35^{\prime} 19.78 \mathrm{~N}, 8^{\circ} 56^{\prime} 42.84 \mathrm{E}$ & 45 & 0.745 & 0.714 & 6.869 & 0.042 & 0.061 & $235(85-\infty)$ \\
\hline T29 & $47^{\circ} 33^{\prime} 19.05 \mathrm{~N}, 9^{\circ} 06^{\prime} 15.47 \mathrm{E}$ & 26 & 0.732 & 0.714 & 7.132 & 0.025 & 0.261 & $94(35-\infty)$ \\
\hline R37 & $47^{\circ} 33^{\prime} 59.08 \mathrm{~N}, 8^{\circ} 25^{\prime} 43.14 \mathrm{E}$ & 49 & 0.713 & 0.712 & 7.165 & 0.001 & 0.505 & $1106(198-\infty)$ \\
\hline R38 & $47^{\circ} 34^{\prime} 42.14 \mathrm{~N}, 8^{\circ} 30^{\prime} 20.53 \mathrm{E}$ & 53 & 0.725 & 0.714 & 7.127 & 0.014 & 0.277 & $700(154-\infty)$ \\
\hline R39 & $47^{\circ} 35^{\prime} 49.36 \mathrm{~N}, 8^{\circ} 35^{\prime} 44.49 \mathrm{E}$ & 49 & 0.669 & 0.655 & 7.390 & 0.021 & 0.205 & $416(142-\infty)$ \\
\hline B1 & $46^{\circ} 52^{\prime} 38.94 \mathrm{~N}, 6^{\circ} 59^{\prime} 40.96 \mathrm{E}$ & 50 & 0.685 & 0.658 & 6.390 & 0.040 & 0.073 & $77(52-135)$ \\
\hline B2 & $46^{\circ} 51^{\prime} 24.14 \mathrm{~N}, 6^{\circ} 57^{\prime} 26.66 \mathrm{E}$ & 47 & 0.661 & 0.662 & 5.955 & -0.001 & 0.478 & $\infty(198-\infty)$ \\
\hline B3 & $46^{\circ} 50^{\prime} 02.50 \mathrm{~N}, 6^{\circ} 56^{\prime} 05.61 \mathrm{E}$ & 50 & 0.685 & 0.655 & 6.390 & 0.044 & 0.050 & $447(121-\infty)$ \\
\hline B4 & $46^{\circ} 48^{\prime} 33.56 \mathrm{~N}, 6^{\circ} 55^{\prime} 39.13 \mathrm{E}$ & 49 & 0.673 & 0.696 & 5.878 & -0.033 & 0.110 & $147(77-\infty)$ \\
\hline B5 & $46^{\circ} 51^{\prime} 23.08 \mathrm{~N}, 6^{\circ} 59^{\prime} 03.35 \mathrm{E}$ & 48 & 0.680 & 0.680 & 6.163 & 0.000 & 0.502 & $203(66-\infty)$ \\
\hline B6 & $46^{\circ} 50^{\prime} 44.43 \mathrm{~N}, 6^{\circ} 54^{\prime} 58.48 \mathrm{E}$ & 49 & 0.653 & 0.628 & 5.965 & 0.039 & 0.098 & $\infty(351-\infty)$ \\
\hline
\end{tabular}




\section{Microsatellite genotyping}

We followed the salting-out protocol of Sunnucks and Hales (1996) adapted to a 96-deep-well format (Gouskov et al. 2016) to extract DNA from fin clips. We used 10 microsatellites amplified in 2 multiplex reactions to genotype individuals: LC128, LC27, LC290, LC32, LC93 (Vyskocilova et al. 2007), LceA149, LceC1, LceCb (Larno et al. 2005), N7G5, and N7K4 (Mesquita et al. 2003). Detailed protocols were published by Gouskov et al. (2016). We visualized the polymerase chain reaction (PCR) products on an ABI 3730 capillary sequencer (Applied Biosystems, Foster City, California), and we used GeneMapper ${ }^{\circledR}$ software (version 4.0; Applied Biosystems) to score them. We used Micro-Checker (van Oosterhout et al. 2004) to test for the possible occurrence of null alleles. Locus LceCb showed evidence of null alleles at the 4 most downstream sites of Thur and Rhine. Therefore, we excluded this locus from all analyses. For the final data set, we considered only individuals with missing data at $\leq 1$ of the remaining 9 loci (1726 genotypes, 32 with 1 missing locus). The numbers of individuals fulfilling this criterion at each site are provided in Table 1.

\section{Descriptive population genetic analyses}

We used the software FSTAT (version 2.9.3.2; Goudet 2002) to calculate expected $\left(H_{e}\right)$ and observed $\left(H_{o}\right)$ heterozygosities and to test for deviations from linkage and Hardy-Weinberg equilibria. We also used FSTAT to calculate allelic richness $(A R)$ standardized for the smallest sample size $(n)$ and $F$-statistics (Weir and Cockerham 1984). The size of the rivers and their permeability to fish migration are expected to affect the effective population size $N_{\mathrm{e}}$. We used the point-estimation method based on linkage disequilibrium (NeEstimator, version 2.0.1; Do et al. 2014) restricted to alleles with frequencies $>0.02$ as recommended by Do et al. (2014) to compare rough estimates of $N_{\mathrm{e}}$ without having temporal samples. We obtained confidence intervals with the jackknife method of Waples and Do (2008).

We used the Bayesian clustering approach implemented in TESS (version 2.3.1; Chen et al. 2007) to obtain a general overview of the genetic structure of European Chub populations. We used this analysis independently for the samples from the Broye and for all samples from the Glatt and the Thur together because these rivers are connected by the Rhine (3 Rhine samples also were included; Fig. 1C). TESS offers the possibility to include the network position of individuals as a spatial prior on cluster membership on the basis of hidden Markov random fields (HMRF) (François et al. 2006). This approach can account for the fact that in a dendritic system, individuals are restricted to move along the waterway to the next population. The spatial relationships among individuals are represented in TESS by a neighborhood system, which requires geographic coordi- nates for each genotype. We obtained these by using the coordinate creator implemented in the software and sampled randomly from a normal distribution around the initial coordinate of the population sample with a standard deviation (SD) of $15 \mathrm{~m}$. The initial neighborhood system was generated automatically with Voronoi tessellation (Guillot et al. 2009) and had to be modified manually with the neighborhood modifying option to reflect the actual river networks. We set the spatial interaction parameter $\psi$ to the default value of $\psi=0.6$ for all analyses. We ran the noadmixture model 20 times for each potential number of clusters $\left(K_{\max }\right)$ with $K_{\max }=2$ to 6 for the Broye and $K_{\max }=$ 2 to 9 for the Thur-Glatt system, with 250,000 sweeps after a burn-in of 50,000 sweeps for each run. The bestsupported number of clusters was determined by plotting the mean deviance information criterion (DIC) of the 20 runs against $K_{\max }$ and choosing the value at which the DIC curve reached a plateau (TESS manual). We processed TESS outputs with CLUMPP (version 1.1.2; Jakobsson and Rosenberg 2007) to account for label switching, and we visualized cluster membership of individuals thereafter with DiSTRUCT (Rosenberg 2004).

\section{Effects of fragmentation on genetic differentiation}

Reduced population connectivity caused by fragmentation should result in a steeper increase of genetic differentiation with distance along the river (isolation-by-distance [IBD]). Therefore, for each river, we calculated the matrices of pairwise $F_{S T}$ among sampled subpopulations in FSTAT. As recommended for populations along linear habitats, we regressed $F_{S T} /\left(1-F_{S T}\right)$ on untransformed riparian distance (Rousset 1997) and used Mantel tests to assess whether isolation-by-distance (IBD) was significant for each river. For the 2 barrier-interrupted rivers (Broye and Glatt) we also carried out partial Mantel tests to assess whether the number of barriers between sites had a significant effect on pairwise differentiation after controlling for riparian distance. Last, we used an Akaike Information Criterion for small sample size (AICc)-based model-selection approach (Burnham and Anderson 1998) to identify the most parsimonious models explaining the genetic structure along the 2 fragmented rivers. We constructed linear models containing all additive combinations of the predictors, distance, and barriers, on linearized $F_{S T}$ (i.e., $F_{S T} /\left[1-F_{S T}\right]$ ), including an intercept-only model, and compared their AICc values. We used the number of sampled populations rather than the number of pairwise combinations as $N$ in the calculation of AICc to account for the nonindependence of pairwise data (Koizumi et al. 2006). The Bayesian clustering in TESS suggested a possible effect of Lake Greifen on genetic structure, so we included the presence or absence of the lake between 2 sampling sites as an additional factor in the set of models predicting pairwise differentiation along the Glatt system. 


\section{Effects of fragmentation on genetic diversity}

Some upstream decline of genetic diversity is a general trend in dendritic landscapes (Morrissey and de Kerckhove 2009), but severe fragmentation is expected to exacerbate this decline by cutting off more upstream populations from the supply of new alleles by immigration. We quantified genetic diversity as $A R$ in FSTAT and analyzed its upstream trend in all 3 river systems. For the Thur-Rhine, this analysis extended from sampling site R38 to T29 $(n=8)$ (Fig. 1C), and for the Glatt it extended from site R37 to G23 $(n=24)$. For the Broye, the analysis included sites G1 to G6, but because they are spread over 3 arms of the river, we arbitrarily selected the lowest confluence as the point from which upstream distances were measured. To compare genetic diversity and its upstream trend among rivers, we ran a linear model on $A R$ that included river as a factor and riparian distance upstream as a covariate, and we used the river-by-distance interaction as a test of whether the upstream trend of $A R$ differed among rivers. For the most densely sampled and most strongly fragmented Glatt system, we used AICc-based model selection to identify the most parsimonious model predicting $A R$ in a set of candidate models comprising all additive combinations of the predictors' upstream distance, barriers, and lake. In this case, the factor, lake, expressed whether or not a sample was from or directly connected to 1 of the 2 lakes in the Glatt system; i.e., distinguishing samples G10, G11, and G13 (Lake Greifen, outflow of Glatt, inflows of Aabach-M and AabachU), and G21 (Lake Pfäffikon) from all other samples.

\section{RESULTS \\ Microsatellite variation and effective population size estimates}

The 9 microsatellite loci analyzed were highly variable and comprised 148 alleles, ranging from 3 to 40 alleles/ locus. We found no strong evidence for linkage among loci. Global linkage disequilibrium (LD) was significant for 2 pairs of loci after Bonferroni correction, but the patterns across populations were very inconsistent, and the vast majority of populations showed no evidence of LD at these locus pairs. Therefore, we considered the loci as unlinked in all analyses. Deviations of observed from expected heterozygosities were small in all populations $\left(F_{I S}\right.$; Table 1$)$, such that Hardy-Weinberg conditions were largely met. Only 1 comparison was marginally significant at $p<0.05$ (heterozygote deficit at site T24), and none were significant after Bonferroni correction (Table 1).

Estimates of $N_{e}$ were variable but generally high with very wide confidence intervals (Table 1 ). For 8 population samples, $N_{e}$ was estimated as infinite and the upper bound of the $95 \%$ confidence interval (CI) reached infinity in most cases. Under these circumstances, the lower bound of the CI may be the most informative parameter estimated, providing plausible limits of $N_{e}$ (Waples and Do 2010). Exclud- ing the Rhine, where only 3 sites were sampled, these lower bounds differed significantly among rivers (Kruskal-Wallis test, $p=0.028$ ), following the order Thur (median lower bound $=252$ ) $>$ Broye (99) $>$ Glatt (58).

\section{Genetic clustering}

For European Chub from the Broye, Bayesian clustering analysis using TESS did not provide any evidence for distinct genetic clusters. Mean DIC declined from $K=2$ toward higher values of $K$, but at $K=2$, most individuals could not be assigned to one of the clusters with high confidence. This result indicates a lack of detectable substructure.

In contrast, for European Chub from the Thur and Glatt river system, Bayesian clustering analysis indicated $K=3$ as the most likely number of genetic clusters, and these clusters had relatively distinct geographic distributions (Fig. 1C). The $1^{\text {st }}$ cluster (yellow) essentially represented the fish from the Thur and Rhine, the $2^{\text {nd }}$ cluster (red) comprised the fish from the Glatt below Lake Greifen and most of the fish from the 2 sampling sites in Aabach-M above the lake, and the $3^{\text {rd }}$ cluster (blue) comprised the fish from Aabach-U above Lake Greifen and the single sample from Lake Pfäffikon, although that sample appeared to show some admixture (Fig. 1C). The distinct genetic clusters present in the Glatt and Aabach-U suggest a role of Lake Greifen in restricting gene flow.

\section{Effects of fragmentation on genetic differentiation}

A significant IBD pattern was observed only in the strongly fragmented Glatt system (Mantel $r=0.460$, 1-tailed $p<0.001$; Fig. 2). The Glatt system comprised 2 genetic clusters, so we also tested separately for IBD along the Glatt below Lake Greifen and along Aabach-U. Both showed significant IBD (Glatt: $r=0.441, p=0.006$; Aabach-U: $r=$ $0.446, p=0.026)$. Along the unfragmented Thur-Rhine sites, genetic differentiation was lower overall (Fig. 2) and IBD was nonsignificant $(r=0.115, p=0.293)$. In fish from the spatially less extensive Broye system with low-height barriers, pairwise differentiation was extremely low. A trend toward increased differentiation with distance was not significant $(r=0.505, p=0.059)$.

Further support for an association of genetic differentiation with anthropogenic fragmentation in the Glatt system was provided by the fact that we observed an even stronger correlation of $F_{S T} /\left(1-F_{S T}\right)$ with the number of barriers between sites $(r=0.641, p<0.001)$, and the fact that partial Mantel tests revealed a significant effect of barriers after accounting for distance $(r=0.510, p<0.001)$, but not for distance corrected for barriers $(r=0.101, p<$ 0.116). In the Broye, no significant correlation between pairwise differentiation and barriers was observed $(r=$ $0.297, p=0.192)$, and this correlation remained nonsignificant after correction for distance $(r=0.309, p=0.213)$. 


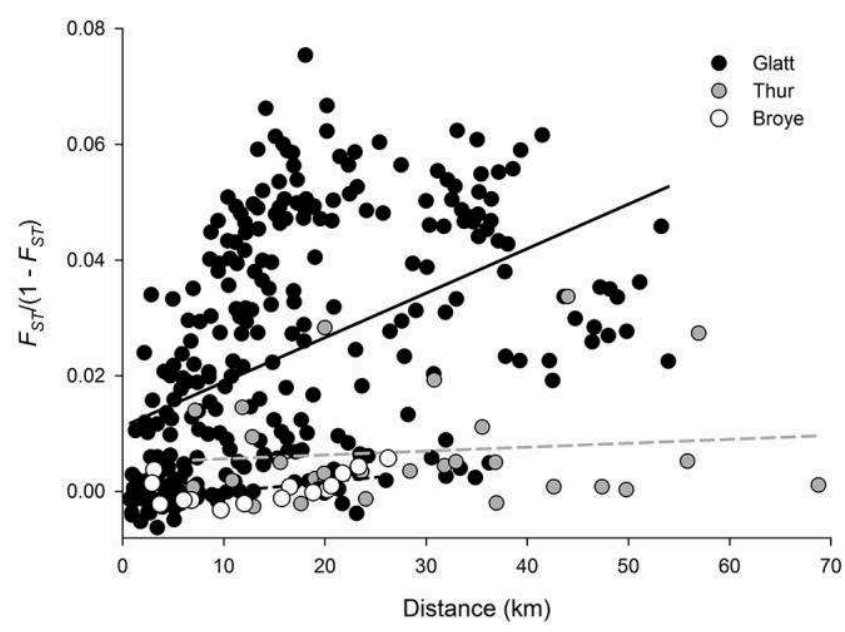

Figure 2. Isolation-by-distance plot depicting the relationship between genetic differentiation of European Chub $\left(F_{S T} /[1-\right.$ $\left.F_{S T}\right]$ ) and distance between pairs of sampling sites for the 3 river systems. Isolation-by-distance was significant only in the Glatt system, as indicated by the continuous line.

The lack of genetic structure in European Chub from the Broye was corroborated by AICc-based model selection, in which the null model fitting an intercept only was identified as the most parsimonious (Table 2). For the Glatt system, the model-selection procedure supported the importance of barriers and Lake Greifen in structuring European Chub populations. The most parsimonious model by far $($ AICc weight $=0.831$; Table 2 ) was the model contain- ing these 2 effects, and the only other model receiving at least some, but considerably less, support from the data $(\triangle \mathrm{AICc}=3.187)$ included these 2 effects and distance (Table 2).

\section{Effects of fragmentation on genetic diversity}

Genetic diversity expressed as $A R$ was highest in European Chub from the large and unfragmented Thur-Rhine system and did not decline significantly upstream ( $\beta=$ $-0.003, R^{2}=0.132, F_{1,6}=0.911, p=0.377$; Fig. 3$)$. In the Broye, the upstream decline of $A R$ also was not significant ( $\left.\beta=-0.038, R^{2}=0.316, F_{1,4}=1.848, p=0.246\right)$, but the low number of samples collected over relatively short distances precluded any strong inference (Fig. 3). In the strongly fragmented Glatt system, a significant upstream decline of AR was observed $\left(\beta=-0.029, R^{2}=0.503, F_{1,22}=22.231, p<\right.$ $0.001)$. When data from the 3 rivers were analyzed jointly, there was a significant effect of river $\left(F_{1,32}=53.754, p<\right.$ $0.001)$ as well as distance $\left(F_{1,32}=18.830, p<0.001\right)$, and the significant river $\times$ distance interaction indicated that the slopes of the upstream decline in $A R$ differed among rivers $\left(F_{2,32}=5.491, p=0.009\right)$. The 3 samples directly connected to Lake Greifen (outflow of Glatt G10, inflows of AabachM G11 and Aabach-U G13) and the only sample from Lake Pfäffikon (G21) in the Glatt system lay substantially above the regression line (Fig. 3), suggestive of an elevated $A R$ in lakes.

The model-selection approach used to evaluate the different influences on $A R$ in the Glatt system is summarized in more detail in Table 3 . The best-supported model con-

Table 2. Results of the model-selection procedure assessing the relative support for candidate models predicting the genetic structure (linearized $F_{S T}$ ) in the 2 rivers affected by anthropogenic fragmentation. The best-supported models are in bold typeface. AICc $=$ Akaike's Information Criterion for small sample sizes, predictors: $\mathrm{c}=$ constant, dist $=$ riparian distance between 2 sampling sites, barr $=$ number of barriers between 2 sampling sites, lake = presence or absence of Lake Greifen between 2 sampling sites.

\begin{tabular}{|c|c|c|c|c|}
\hline Effects in model & Log likelihood & $\mathrm{AICc}$ & $\triangle \mathrm{AICc}$ & Akaike weight \\
\hline \multicolumn{5}{|l|}{ Broye } \\
\hline c & 68.164 & -128.328 & 0.000 & 0.931 \\
\hline$c+$ dist & 70.369 & -122.738 & 5.590 & 0.057 \\
\hline$c+$ barr & 68.854 & -119.709 & 8.620 & 0.013 \\
\hline$c+$ dist + barr & 71.123 & -94.246 & 34.082 & 0.000 \\
\hline \multicolumn{5}{|l|}{ Glatt system } \\
\hline $\mathrm{c}$ & 676.478 & -1348.384 & 205.006 & 0.000 \\
\hline$c+$ dist & 709.339 & -1411.479 & 141.911 & 0.000 \\
\hline$c+$ barr & 749.576 & -1491.953 & 61.438 & 0.000 \\
\hline $\mathrm{c}+$ lake & 743.187 & -1479.174 & 74.216 & 0.000 \\
\hline$c+$ dist + barr & 750.998 & -1491.891 & 61.499 & 0.000 \\
\hline$c+$ dist + lake & 751.553 & -1493.001 & 60.389 & 0.000 \\
\hline c + barr + lake & 781.748 & -1553.390 & 0.000 & 0.831 \\
\hline$c+$ dist + barr + lake & 781.768 & -1550.203 & 3.187 & 0.169 \\
\hline
\end{tabular}




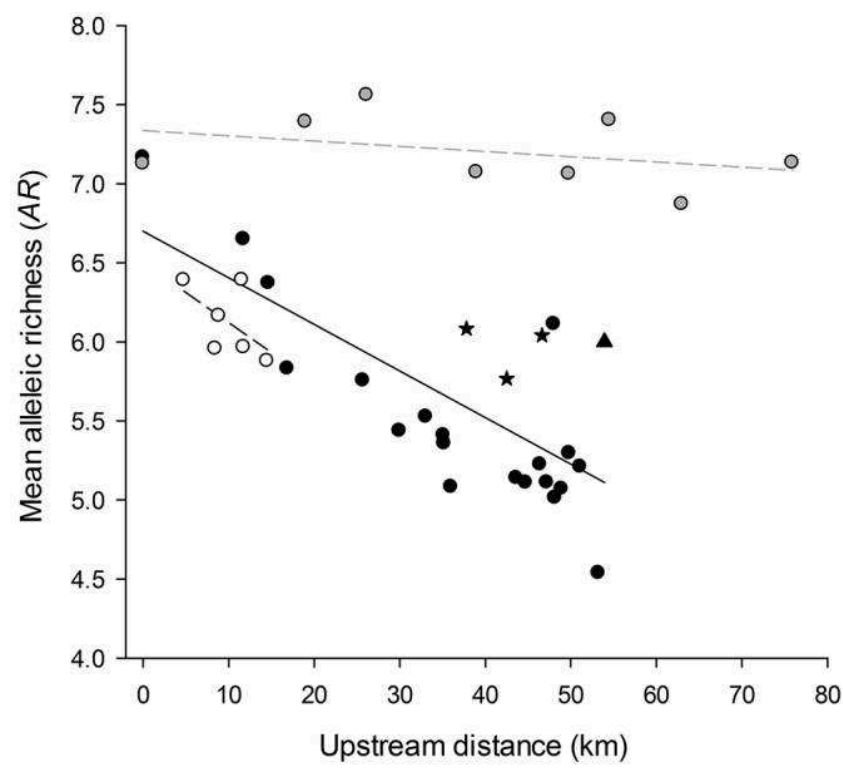

Figure 3. Upstream decline of allelic richness $(A R)$ in the 3 river systems. Black symbols represent the Glatt system, gray symbols the Thur, and open symbols the Broye. The dashed regression lines represent nonsignificant relationships. The solid regression line is significant (see text). The black triangle represents the sample from Lake Pfäffikon, and the black stars represent the most upstream sample from the Glatt River and the most downstream samples from Aabach-M and Aabach U, which are not separated by any barriers from Lake Greifen.

tained the effects of distance and lake (Akaike weight $=$ 0.823), and the only other model receiving any support contained the same effects and barriers. All other models containing the effect of barriers received no support. Overall, these results indicate elevated $A R$ in lakes and suggest that for European Chub in the Glatt system, upstream distance from the most downstream site is a better predictor of genetic diversity than the number of barriers along this distance, but these variables are correlated $(r=0.836)$.

\section{DISCUSSION}

Our analysis of European Chub populations in 3 Swiss midland rivers with variable levels of anthropogenic fragmentation revealed marked differences in genetic structure and diversity. Most instructive was the comparison between the adjacent Thur and Glatt, which could be investigated over a similar length and drain into the same river (Rhine) in close proximity. European Chub from the unfragmented Thur possessed higher allelic diversity overall, showed no significant IBD and only a weak and nonsignificant upstream decline in $A R$. Fish from the strongly fragmented Glatt were less genetically diverse overall, exhibited significant IBD and a steep upstream decline of $A R$. Similar patterns were observed in European Chub from the fragmented Durance River in France (Dehais et al. 2010). However, the comparison between the Thur and Glatt was not entirely fair because the unfragmented Thur is considerably larger than the Glatt $(\sim 5 \times$ discharge; see Methods). Assuming similar habitat suitability for the European Chub, lower population sizes and, thus, a more important influence of genetic drift in the Glatt also would be expected in the absence of any differences in fragmentation. Two lines of evidence indicate that the large numbers of man-made barriers in the Glatt do indeed contribute to the observed differences. First, the partial Mantel tests and the most parsimonious predictive model (Table 2) indicate that the IBD pattern in the Glatt system largely reflects 'isolation-by-barriers'. Second, the Broye is very similar in size to the Glatt but fragmented only by low-height barriers that are traversable by European Chub. There, the fish show much lower genetic differentiation over similar distances than in the Glatt (Fig. 2), where barriers are mostly impermeable to European Chub migration. We are

Table 3. Results of the model-selection procedure assessing the relative support for candidate models predicting genetic diversity (allelic richness $=A R$ ) in the Glatt system. The best-supported model is in bold type. AICc = Akaike's Information Criterion for small sample sizes; predictors: $\mathrm{c}=$ constant, dist $=$ riparian distance from most downstream site, barr = number of barriers between sampling sites and most downstream site, lake = factor indicating if the sampling site was in a lake or directly connected to a lake (sites G10, G11, G13, and G21) or not (all other sites).

\begin{tabular}{lcccc}
\hline \multicolumn{1}{c}{ Effects in model } & Log likelihood & AICc & $\Delta$ AICc & Akaike weight \\
\hline c & -21.373 & 47.317 & 25.576 & 0.000 \\
c + dist & -12.992 & 33.184 & 11.443 & 0.003 \\
c + barr & -15.233 & 37.666 & 15.925 & 0.000 \\
c + lake & -20.34 & 47.880 & 26.139 & 0.000 \\
c + dist + barr & -12.86 & 35.825 & 14.084 & 0.001 \\
c + dist + lake & $-\mathbf{5 . 8 1 8}$ & $\mathbf{2 1 . 7 4 1}$ & 0.000 & $\mathbf{0 . 8 2 3}$ \\
c + barr + lake & -12.65 & 35.405 & 13.664 & 0.001 \\
c + dist + barr + lake & -5.769 & 24.871 & 3.130 & 0.172 \\
\hline
\end{tabular}


convinced that the fragmentation-associated genetic structure in the Glatt system comes about by physical obstruction to dispersal rather than any unsuitable habitat created by impoundments, because the European Chub is a habitat generalist that thrives in lentic and lotic conditions. Accordingly, it is highly abundant along the entire Glatt system. A recent study by Roberts et al. (2013) on the endangered Roanoke Logperch (Percina rex) in the eastern USA also found virtually free gene flow along unimpounded river distances comparable to those along the Thur and Glatt in the present study, but strong differentiation across barriers, which were hydroelectric dams unequipped with fish passes.

$N_{e}$ could not be estimated with high precision, but at least the lower bounds seem to be higher in the Broye than in the similar-sized Glatt, consistent with a positive effect of connectivity on $N_{e}$ (Palstra and Ruzzante 2008). Thus, low-height drops $<\sim 0.5 \mathrm{~m}$, even when very numerous such as those found in the Broye, do not appear to present important barriers to gene flow for the European Chub. We acknowledge that the spatial extent of the Broye system is smaller than that of the Glatt system, and this difference may have affected the opportunity to detect genetic structure. On the other hand, $A R$ in the Broye is comparable to that in the similar-sized Glatt below Lake Greifen (Fig. 3), but the average level of genetic differentiation over the 0 to $25 \mathrm{~km}$ range is lower than in the Glatt and more similar to that in the large and unfragmented Thur (Fig. 2). This result suggests that population connectivity is little affected by the low-head barriers in the Broye. However, the same types of barriers may have a much stronger effect on other species, e.g., fishes with small body size like Sticklebacks (Raeymaekers et al. 2009) or grounddwelling species with poor swimming ability like Bullhead (Cottus gobio) (Junker et al. 2012).

The Bayesian clustering analyses revealed an interesting role of the 2 lakes for the genetic structure and diversity of European Chub in the highly fragmented Glatt system. That European Chub from the Glatt and from Aabach-U are mostly assigned to 2 distinct genetic clusters (Fig. 1C) is suggestive of Lake Greifen acting as an obstacle to dispersal, even though European Chub clearly thrive in the lake and in the river habitat. On the other hand, the inflow of Aabach-M is even further away from the outflow of the Glatt, and European Chub from Aabach-M are genetically very similar to those from the Glatt. This result does not support reduced gene flow across the lake. An alternative explanation would be that lakes serve as important source populations that supply large numbers of recruits, whichat least in a highly fragmented system like the Glatt drainage-predominantly pass obstacles in the direction of flow and, thus, influence the genetic composition at downstream locations. This explanation is consistent with the observation that the distinct genetic composition of Euro- pean Chub from Aabach-U is very similar to that of Lake Pfäffikon, which drains into Aabach-U (Fig. 1C). This lake is well separated from the rest of the Glatt system by a barrier that was originally natural and now is further obstructed by a hydroelectric power station exploiting the natural drop in terrain, but movement downstream from the lake by drifting European Chub larvae is still possible. Lake Pfäffikon seems to show some admixture from the genetic cluster associated with the Glatt further downstream (Fig. 1C). A feasible reason could be the occasional movement from Lake Greifen of small European Chub used as live bait by recreational fisherman. Both lakes can be fished with the same license.

Both lakes appear to act as reservoirs of genetic diversity because the sample from Lake Pfäffikon and the samples from sites directly connected to Lake Greifen showed elevated $A R$ compared to river sites. This finding probably reflects that because of their size, the lakes can support very large populations of European Chub, although the $N_{e}$ estimates obtained do not substantiate this claim (Table 1). However, these estimates come with such wide CIs that they cannot be taken as evidence against higher $N_{e}$ in lakes.

In contrast to genetic differentiation, genetic diversity (expressed as $A R$ ) was not clearly associated with fragmentation by barriers in the Glatt system. That distance upstream was a better predictor of $A R$ than the number of barriers along this distance was largely a result of the situation in Aabach-U below Lake Pfäffikon. There, many samples collected over a short distance had very similar $A R$ (sites G14-G22, the dense cloud of black circles in Fig. 3), even though they are separated by a large number of barriers along this short distance (Fig. 1C). The comparisons with the unfragmented Thur, in which the upstream decline in $A R$ was very shallow and nonsignificant, suggest that fragmentation may at least contribute to the significant upstream decline in the Glatt.

\section{Implications for river management}

Effects of anthropogenic fragmentation on fish population connectivity have been reported in a number of cases (e.g., Bessert and Orti 2008, Faulks et al. 2011, Junge et al. 2014). That anthropogenic fragmentation has detectable effects on the genetic structure and diversity of European Chub populations is significant because in many respects, the European Chub represents the best-case scenario of a fish that should be resilient to fragmentation effects. It occurs at high population densities, it is a strong swimmer able to migrate long distances and to traverse at least low barriers (Broye), and it is very tolerant of habitat alterations that typically accompany river fragmentation (e.g., altered flow regime and substrate). Accordingly, the overall population structure is very shallow in this fish. The 
global $F_{S T}$ value over all sampling sites across Thur, Rhine, and the Glatt system was only $0.036 \pm 0.003(\mathrm{SE})$. Thus, improving population connectivity across man-made obstacles in the European Chub would appear to be relatively straightforward, e.g., by installment of fish bypasses, which European Chub accept readily (Guthruf 2008). However, the effects of river fragmentation are species-specific (Blanchet et al. 2010), and small ground-dwelling fish like bullheads, loaches, or gudgeons could be more strongly affected by the same level of fragmentation. Thus, the goal of re-establishing free fish migration in the course of river restorations, explicitly requested in the Swiss legislation by the revised Water Protection Act (Könitzer et al. 2012) and in the European Water Framework Directive (EU WFD 2000), must be pursued. However, such restorations also may ease access to previously uninvaded rivers by invasive fish or aquatic invertebrates (Rahel 2013), which are a growing problem worldwide (Strayer 2010). This possibility will require some difficult choices by river managers and calls for informed pragmatism in the face of conflicting conservation goals in river restoration.

\section{ACKNOWLEDGEMENTS}

We thank numerous helpers in the field, including C. Elmiger, C. Mayer, Y. Sieber, S. Hocevar, L. Bitterlin, L. Gehrer, B. Gouskov, G. Gouskov, M. Moest, M. Reyes, R. Rouchet, and T. Zuberbühler. Electrofishing equipment was kindly provided by FORNAT AG. We also thank J. Van Buskirk, T. Torossi, D. Hefti, L. Keller, and A. Peter for useful discussions and the referees for helpful comments on the manuscript. The fisheries departments of the Cantons Freiburg, Waadt, Thurgau, and Zurich are acknowledged for fishing permits. The veterinarian office of Canton Zurich issued the animal experimentation permission. All molecular data were generated in the Genetic Diversity Centre of ETH Zurich. This study was financed by the Federal Office for the Environment (FOEN), the Swiss Federal Institute of Aquatic Science and Technology (Eawag), the Swiss Federal Institute of Technology Zurich (ETHZ), and the Fisheries Department of the Canton Bern.

\section{LITERATURE CITED}

Bessert, M. L., and G. Orti. 2008. Genetic effects of habitat fragmentation on blue sucker populations in the upper Missouri River (Cycleptus elongatus Lesueur, 1918). Conservation Genetics 9:821-832.

Blanchet, S., O. Rey, R. Etienne, S. Lek, and G. Loot. 2010. Speciesspecific responses to landscape fragmentation: implications for management strategies. Evolutionary Applications 3:291-304.

Burnham, K. P., and D. R. Anderson. 1998. Model selection and inference. Springer, New York.

Chen, C., E. Durand, F. Forbes, and O. François. 2007. Bayesian clustering algorithms ascertaining spatial population structure: a new computer program and a comparison study. Molecular Ecology Notes 7:747-756.

de Leeuw, J. J., and H. V. Winter. 2008. Migration of rheophilic fish in the large lowland rivers Meuse and Rhine, The Netherlands. Fisheries Management and Ecology 15:409-415.
Dehais, C., R. Eudeline, P. Berrebi, and C. Argillier. 2010. Microgeographic genetic isolation in chub (Cyprinidae: Squalius cephalus) population of the Durance River: estimating fragmentation by dams. Ecology of Freshwater Fish 19:267-278.

Do, C., R. S. Waples, D. Peel, G. M. Macbeth, B. J. Tillett, and J. R. Ovenden. 2014. NeEstimator v2: re-implementation of software for the estimation of contemporary effective population size (N-e) from genetic data. Molecular Ecology Resources 14:209-214.

EU WFD (European Union Water Framework Directive) 2000. Directive 2000/60/EC of the European Parliament and of the Council of 23 October 2000 establishing a framework for Community action in the field of water policy. Official Journal of the European Communities L 327:1-72.

Faulks, L. K., D. M. Gilligan, and L. B. Beheregaray. 2011. The role of anthropogenic vs. natural in-stream structures in determining connectivity and genetic diversity in an endangered freshwater fish, Macquarie Perch (Macquaria australasica). Evolutionary Applications 4:589-601.

Fausch, K. D., C. E. Torgersen, C. V. Baxter, and H. W. Li. 2002. Landscapes to riverscapes: bridging the gap between research and conservation of stream fishes. BioScience 52:483-498.

Fluker, B. L., B. R. Kuhajda, and P. M. Harris. 2014. The effects of riverine impoundment on genetic structure and gene flow in two stream fishes in the Mobile River basin. Freshwater Biology 59:526-543.

François, O., S. Ancelet, and G. Guillot. 2006. Bayesian clustering using hidden Markov random fields in spatial population genetics. Genetics 174:805-816.

Fredrich, F., S. Ohmann, B. Curio, and F. Kirschbaum. 2003. Spawning migrations of the chub in the River Spree, Germany. Journal of Fish Biology 63:710-723.

Gerster, S. 1991. Hochrhein-Fischfauna im Wandel der Zeit. Bundesamt für Umwelt, Wald und Landschaft, Bern, Switzerland.

Goudet, J. 2002. FSTAT 2.9.3.2, a program to estimate and test gene diversities and fixation indices. University of Lausanne, Lausanne, Switzerland. (Available from: http://www2.unil.ch /popgen/softwares/fstat.htm).

Gouskov, A., M. Reyes, L. Wirthner-Bitterlin, and C. Vorburger. 2016. Fish population genetic structure shaped by hydroelectric power plants in the upper Rhine catchment. Evolutionary Applications 9:394-408.

Guillot, G., R. Leblois, A. Coulon, and A. C. Frantz. 2009. Statistical methods in spatial genetics. Molecular Ecology 18:4734-4756.

Guthruf, J. 2008. Fischaufstieg am Hochrhein. Koordinierte Zählung 2005/06. Umwelt-Wissen BAFU, Federal Office for the Environment, Bern, Switzerland. (Available from: http:// www.bafu.admin.ch/publikationen/publikation/00090/index .html?lang=de).

Hudman, S. P., and K. B. Gido. 2013. Multi-scale effects of impoundments on genetic structure of Creek Chub (Semotilus atromaculatus) in the Kansas River basin. Freshwater Biology 58:441-453.

Jakobsson, M., and N. A. Rosenberg. 2007. CLUMPP: a cluster matching and permutation program for dealing with label switching and multimodality in analysis of population structure. Bioinformatics 23:1801-1806.

Junge, C., J. Museth, K. Hindar, M. Kraabol, and L. A. Vollestad. 2014. Assessing the consequences of habitat fragmentation 
for two migratory salmonid fishes. Aquatic Conservation: Marine and Freshwater Ecosystems 24:297-311.

Junker, J., A. Peter, C. E. Wagner, S. Mwaiko, B. Germann, O. Seehausen, and I. Keller. 2012. River fragmentation increases localized population genetic structure and enhances asymmetry of dispersal in Bullhead (Cottus gobio). Conservation Genetics 13:545-556.

Kirchhofer, A., M. Breitenstein, and B. Zaugg. 2007. Rote Liste der gefährdeten Arten der Schweiz: Fische und Rundmäuler der Schweiz. Umwelt-Vollzug, Bundesamt für Umwelt, Schweizer Zentrum für die Kartographie der Fauna, Bern, Switzerland. (Available from: http://www.bafu.admin.ch/publikationen/pub likation/00071/index.html?lang=de)

Koizumi, I., S. Yamamoto, and K. Maekawa. 2006. Decomposed pairwise regression analysis of genetic and geographic distances reveals a metapopulation structure of stream-dwelling Dolly Varden Charr. Molecular Ecology 15:3175-3189.

Könitzer C., C. Zaugg, T. Wagner, J.-C. Pedroli, and L. Mathys. 2012: Wiederherstellung der Fischwanderung - Strategische Planung. Ein Modul der Vollzugshilfe Renaturierung der Gewässer. Bundesamt für Umwelt, Bern. Umwelt-Vollzug 1209: 54. (Available from: http://www.bafu.admin.ch/publikationen /publikation/01643/index.html?lang=de)

Kottelat, M., and J. Freyhof. 2007. Handbook of European freshwater fishes. Published by the authors, Cornol, Switzerland and Berlin, Germany.

Larno, V., S. Launey, A. Devaux, and J. Laroche. 2005. Isolation and characterization of microsatellite loci from chub Leuciscus cephalus (Pisces: Cyprinidae). Molecular Ecology Notes 5:752-754.

Liermann, C. R., C. Nilsson, J. Robertson, and R. Y. Ng. 2012. Implications of dam obstruction for global freshwater fish diversity. BioScience 62:539-548.

Limburg, K. E., and J. R. Waldman. 2009. Dramatic declines in North Atlantic diadromous fishes. BioScience 59:955-965.

McLaughlin, R. L., L. Porto, D. L. G. Noakes, J. R. Baylis, L. M. Carl, H. R. Dodd, J. D. Goldstein, D. B. Hayes, and R. G. Randall. 2006. Effects of low-head barriers on stream fishes: taxonomic affiliations and morphological correlates of sensitive species. Canadian Journal of Fisheries and Aquatic Sciences 63:766-779.

Mesquita, N., C. Cunha, B. Hänfling, G. R. Carvalho, L. Zé-Zé, R. Tenreiro, and M. M. Coelho. 2003. Isolation and characterization of polymorphic microsatellite loci in the endangered Portuguese freshwater fish Squalius aradensis (Cyprinidae). Molecular Ecology Notes 3:572-574.

Morrissey, M. B., and D. T. de Kerckhove. 2009. The maintenance of genetic variation due to asymmetric gene flow in dendritic metapopulations. American Naturalist 174:875-889.

Palstra, F. P., and D. E. Ruzzante. 2008. Genetic estimates of contemporary effective population size: what can they tell us about the importance of genetic stochasticity for wild population persistence? Molecular Ecology 17:3428-3447.

Penczak, T., L. Glowacki, W. Galicka, and H. Koszaliński. 1998. A long-term study (1985-1995) of fish populations in the impounded Warta River, Poland. Hydrobiologia 368:157-173.

Raeymaekers, J. A. M., D. Raeymaekers, I. Koizumi, S. Geldof, and F. A. M. Volckaert. 2009. Guidelines for restoring connectivity around water mills: a population genetic approach to the management of riverine fish. Journal of Applied Ecology 46:562-571.

Rahel, F. J. 2013. Intentional fragmentation as a management strategy in aquatic systems. BioScience 63:362-372.

Roberts, J. H., P. L. Angermeier, and E. M. Hallerman. 2013. Distance, dams and drift: what structures populations of an endangered, benthic stream fish? Freshwater Biology 58:20502064.

Rosenberg, N. A. 2004. DISTRUCT: a program for the graphical display of population structure. Molecular Ecology Notes 4: 137-138.

Rousset, F. 1997. Genetic differentiation and estimation of gene flow from $F$-statistics under isolation by distance. Genetics 145 : $1219-1228$

Stockwell, C. A., A. P. Hendry, and M. T. Kinnison. 2003. Contemporary evolution meets conservation biology. Trends in Ecology and Evolution 18:94-101.

Stoll, S., A. Sundermann, A. W. Lorenz, J. Kail, and P. Haase. 2013. Small and impoverished regional species pools constrain colonisation of restored river reaches by fishes. Freshwater $\mathrm{Bi}$ ology 58:664-674.

Strayer, D. L. 2010. Alien species in fresh waters: ecological effects, interactions with other stressors, and prospects for the future. Freshwater Biology 55:152-174.

Sunnucks, P., and D. F. Hales. 1996. Numerous transposed sequences of mitochondrial cytochrome oxidase I-II in aphids of the genus Sitobion (Hemiptera: Aphididae). Molecular Biology and Evolution 13:510-524.

Tockner, K., and J. A. Stanford. 2002. Riverine flood plains: present state and future trends. Environmental Conservation 29: 308-330.

van Oosterhout, C., W. F. Hutchinson, D. P. M. Wills, and P. Shipley. 2004. MICRO-CHECKER: software for identifying and correcting genotyping errors in microsatellite data. Molecular Ecology Notes 4:535-538.

Vischer, D. L. 2003. Die Geschichte des Hochwasserschutzes in der Schweiz. Berichte des Bundesamt für Wasser und Geologie, Serie Wasser. Bundesamt für Wasser und Geologie, Bern, Switzerland.

Vörösmarty, C. J., P. B. McIntyre, M. O. Gessner, D. Dudgeon, A. Prusevich, P. Green, S. Glidden, S. E. Bunn, C. A. Sullivan, C. R. Liermann, and P. M. Davies. 2010. Global threats to human water security and river biodiversity. Nature 467:555561.

Vyskočilová, M., A. Šimková, and J. F. Martin. 2007. Isolation and characterization of microsatellites in Leuciscus cephalus (Cypriniformes, Cyprinidae) and cross-species amplification within the family Cyprinidae. Molecular Ecology Notes 7:11501154.

Waples, R. S., and C. Do. 2008. LDNE: a program for estimating effective population size from data on linkage disequilibrium. Molecular Ecology Resources 8:753-756.

Waples, R. S., and C. Do. 2010. Linkage disequilibrium estimates of contemporary $\mathrm{N}_{\mathrm{e}}$ using highly variable genetic markers: a largely untapped resource for applied conservation and evolution. Evolutionary Applications 3:244-262.

Weir, B. S., and C. C. Cockerham. 1984. Estimating F-statistics for the analysis of population structure. Evolution 38:13581370. 
Zaugg, B., P. Stucki, J.-C. Pedroli, and A. Kirchhofer. 2003. Pisces: Atlas. Fauna Helvetica. $7^{\text {th }}$ edition. CSCF/SZKF, Neuchâtel, Switzerland.

Zeh Weissmann, H., C. Könitzer, and A. Bertiller. 2009. Strukturen der Fliessgewässer in der Schweiz: Zustand von Sohle,
Ufer und Umland (Ökomorphologie); Ergebnisse der ökomorphologischen Kartierung. Stand: April 2009. Umwelt-Zustand, Federal Office for the Environment, Bern, Switzerland. (Available from: http://www.bafu.admin.ch/publikationen/publikation /01075/index.html?lang=de) 